\title{
Светокультура
}

\section{УСТОЙЧИВОСТЬ РАССАДЫ ДЕКОРАТИВНЫХ РАСТЕНИЙ К КРАТКОВРЕМЕННОМУ ХОЛОДОВОМУ СТРЕССУ ПРИ ВОЗДЕЙСТВИИ УЗКОСПЕКТРАЛЬНОГО СВЕТА}

\author{
В.В. КОНДРАТЬЕВА, Т.В. ВОРОНКОВА, Л.С. ОЛЕХНОВИЧ, Г.Ф. БИДЮКОВА, \\ О.Л. ЕНИНА, О.В. ШЕЛЕПОВА
}

\begin{abstract}
Узкоспектральный свет светодиодных ламп в сочетание с естественным освещением изменяет направленность и интенсивность метаболических процессов в растении, что позволяет ему адаптироваться к меняющимся условиям внешней среды. В представленной работе мы впервые показали, что досветка узкоспектральным светом позволяет рассаде декоративных растений успешно адаптироваться к холодовому стрессу. Нашей целью было изучение влияния красного $(\lambda=600$ нм) и синего $(\lambda=400$ нм) света от светодиодных панелей ПС-2 (УСС-12) («Фокус», Россия) на жизнеспособность и приживаемость рассады низкорослых сортов тагетиса (Tagetis panula L.) сорта Karmen, львиного зева (Antirrhinum majus nanum L.) сорта Flora shower white и петунии (Petunia hybrida L.) сорта Mambo blue в условиях возвратных весенних заморозков. Контролем были растения, выращенные при естественном освещении. Выбранные для опыта растения часто используются в озеленении населенных пунктов и подвержены воздействию низких положительных и нулевых температур, особенно в первые дни после пересадки в открытый грунт. Эффективность досветки оценивали по декоративному состоянию растений, изменению избирательной проницаемости мембран, содержанию в тканях листьев триггеров каскада протекторных реакций: водорастворимых углеводов, салициловой (СК) и абсцизовой (АБК) кислот, приживаемости растений после пересадки в открытый грунт. Установлено, что досветка красным (КС) и синим (СС) светом способствовала формированию устойчивости рассады к низким положительным температурам. Холодовой стресс вызвал нарушение полупроницаемости клеточных мембран во всех вариантах опыта, но оно было минимальным у растений при досветке КС и СС: выход электролитов снизился по сравнению с контролем у петунии на 51-52 \%, у львиного зева - на 9$37 \%$, у тагетиса $-12-18 \%$. При досветке после холодового стресса значимо $(\mathrm{p} \leq \mathbf{0 , 0 5})$ снизились выход ионов калия и содержание салициловой кислоты - на 9-14 \% (КС) и 21-37 \% (СС), возросло содержание моносахаров. После холодового стресса у тагетиса быстро восстанавливался тургор в варианте КС, но в контроле и при использовании СС этот процесс был замедлен, на краях листьев имелись повреждение. Растения львиного зева и петунии при досветке (КС и СС) быстро восстанавливались, у них сохранялся габитус, близкий к исходному, началась бутонизация. У контрольных растений восстановление шло медленнее, их декоративные качества были низкими. После воздействия холодового стресса при пересадке в открытый грунт в варианте КС достигала $100 \%$, у львиного зева $-85-90 \%$, в случае СС у тагетиса $-70 \%$, у петунии 85-90\%. Контрольные растения, выращенные при естественном освещени, после холодового стресса приживались на 60-70\%. Добавление к естественному освещению узкоспектрального света при выращивании рассады декоративных растений может быть весьма эффективно и позволит снизить гибель растений от возвратных весенних заморозков.
\end{abstract}

Ключевые слова: Tagetis panula L., тагетис, сорт Karmen, Antirrhinum majus nanum L., львиный зев, сорт Flora shower white, Petunia hybrida L., петуния, сорт Mambo blue, узкоспектральный свет, холодовой стресс, клеточные мембраны, водорастворимые углеводы, салициловая кислота, абсцизовая кислота.

Адаптация растений к изменению температурных условий среды часто сопровождается стрессом. Это сложный многоступенчатый процесс, выяснение механизмов которого важно как в научном, так и в практическом аспекте.

Узкоспектральный свет от светодиодных панелей в сочетании с естественным освещением существенно меняет интенсивность и направленность метаболических процессов в растении $(1,2)$. Использование светодиодных ламп и панелей в новых технологиях закрытого грунта становится доминирующим в оранжерейном хозяйстве (3). Однако физиологобиохимические основы адаптации остаются недостаточно изученными. 
Интенсивность освещения, его продолжительность и длина волны могут вызвать экспрессию определенных генов и синтез ряда новых веществ, влияющих на генеративные органы растений $(4,5)$. Есть предположение, что эффект узкоспектральный свет связан с активацией COR-генов, инициирующих синтез белков холодового стресса $(6,7)$. В этот каскад взаимосвязанных преобразований вовлекаются несколько светозависимых реакций, что существенно корректирует метаболизм растения: меняется гормональный и углеводный статус клеток, проницаемость их мембран, активируется или ингибируется работа некоторых ферментов (8-10). Повышение устойчивости растений к гипотермии связано с подавлением окислительного стресса за счет связывания активных форм кислорода (АФК) и свободных радикалов, благодаря действию антиоксидантных ферментов и накоплению низкомолекулярных органических антиоксидантов $(11,12)$. При адаптации к холодовому стрессу растения аккумулируют стресс-протекторные вещества - аминокислоты, растворимые сахара, сахароспирты и другие метаболиты.

Высказывается мнение, что COR-гены активируются при облучении красным $(\lambda=660$ нм) и синим $(\lambda=400$ нм $)$ светом, то есть в регуляцию экспрессии этих генов вовлекаются световоспринимающие рецепторы фитохромы и криптохромы $(13,14)$. Информация о стабилизирующем влиянии красного и синего света при регуляции экспрессии генов в стрессовых условиях позволяет предположить наличие первичных элиситорных сигналов различной природы. Адаптацию к понижению температуры моделирует ряд взаимосвязанных процессов, позволяющих растению изменить клеточный и метаболический гомеостаз (15). Существенную роль в работе этих каскадных механизмов играют салициловая (CK) и абсцизовая (АБК) кислоты. СК - один из метаболитов, инициирующих экспрессию генов синтеза ферментов антиоксидантной защиты, что позволяет контролировать АФК, сохранить целостность клеточных мембран и окислительно-восстановительный статус клеток растения (16-18). Накопление АБК в тканях включает АБК-сигнальный каскад, который завершается экспрессией COR-генов, определяющую холодовую толерантность вида (19).

B представленной работе мы впервые показали, что воздействие узкоспектральным светом позволяет рассаде декоративных растений успешно адаптироваться к холодовому стрессу.

Цель работы - определить, влияет ли предварительная досветка красным или синим светом на устойчивость рассады к непродолжительному воздействию низких положительных температур при весенних заморозках.

Методика. Для исследования были выбраны декоративные растения, часто используемые в открытом грунте при озеленении городов львиный зев (Antirrhinum majus nanum L.), низкорослый сорт Flora shower white, тагетис (Tagetis panula L.), низкорослый сорт Karmen, и многоцветковая петуния (Petunia hybrida L.) сорта Mambo blue. Растения в стадии 57-го листа высаживали в сосуды с песком (по 5 растений, в каждом варианте по 15 сосудов). Растения выращивали в полуконтролируемых условиях: к естественному свету добавляли красный (max $\lambda=600$ нм) (1-й вариант, КС) или синий $(\max \lambda=400$ нм) (2-й вариант, СС). Интенсивность (плотность фотонов) для $\mathrm{KC} \mathrm{и} \mathrm{СС} \mathrm{-} \mathrm{соответственно} 2,58 \times 10^{18}$ и $6,04 \times 10^{18}$ фотонов $/\left(\mathrm{M}^{2} \cdot \mathrm{c}\right)$. В качестве дополнительных источников света использовали светодиодные лампы модели ПС-2 (УСС-12) («Фокус», Россия). Досветку растений проводили ежедневно по 12 ч. Контролем (3-й вариант - К) служили растения, выращенные при естественном освещении. Полив дистиллированной водой осуществляли ежедневно, подкормку проводили 1 
раз в неделю 150 мл питательной смесью Кнопа (0,25 г фосфата калия, 0,25 г сульфата магния, 1 г кальциевой селитры и 0,125 г хлористого калия на 1 л дистиллированной воды). После окончания досветки половину растений из каждого варианта (KC, СC, К) помещали на 24 ч в камеру с температурой $2{ }^{\circ} \mathrm{C}$, оставшиеся (контроль) оставляли без охлаждения.

Пробы для биохимических анализов брали на 35-е (после окончания досветки) и 37-е сут (на 2-е сут после воздействия холодового стресca). Для определения функционального состояния мембран клеток навеску листьев 0,3 г помещали в бидистиллят, выдерживали 24 ч в термостате при температуре $26{ }^{\circ} \mathrm{C}$ и измеряли электропроводность элюата, определяли в нем содержание ионов $\mathrm{K}^{+}$потенциометрически с использованием ионоселективных электродов (рН-метр/иономер ИТАН, ООО «НПП «Томьаналит», Россия; ионоселективный электрод Элит-031, ООО «НИКО Аналит», Россия) по ранее опубликованной методике (20).

Содержание моносахаров определяли спектрофотометрически (Specol 1300, «Analytik Jena AG», Германия) по пикриновой кислоте (21). Количество салициловой (CK) и абсцизовой (АБК) кислот анализировали из одной навески: 2 г сырых листьев экстрагировали этанолом (80\%), экстракт упаривали до водной фазы, которую делили на две равные по объему части. Для выделения СК и АБК экстракт очищали по модифицированной в лаборатории методике (22). На заключительном этапе использовали изократическую высокоэффективную жидкостную хроматографию (изократический хроматограф Стайер, ЗАО «Аквилон», Россия) с колонкой RP-18 (250/4,6 мм) («Phenomenex, Inc.», США).

Статистическую обработку данных проводили с применением программ Excel 2010 и Past v3.0 (23). Определяли средние значения изучаемых показателей $(M)$, стандартные ошибки средних ( \pm SEM) и доверительный интервал при $95 \%$ доверительном уровне $\left(t_{0,05} \times \mathrm{SEM}\right)$. Достоверность различий между вариантами оценивали методом непараметрической (критерий парных сравнений Шапиро-Уилкоксона) статистики. Различия между вариантами считали достоверными при $\mathrm{p} \leq 0,05$.

Результаты. Перепады суточных температур в весенний и осенний периоды часто вызывают повреждения и даже гибель растений. Температура, использованная нами для моделирования холодового стресса $\left(2{ }^{\circ} \mathrm{C}\right)$, не летальна для изучаемых растений, но может вызвать существенные повреждения листьев (24).

После окончания досветки КС и СС светом особых различий по габитусу и морфологии у тагетиса по вариантам не было (рис. 1, А). И в опыте, и в контроле отмечали хороший тургор листьев, почти у $30 \%$ растений началась бутонизация. У львиного зева и петунии после досветки КС увеличилась биомасса надземной части растений (соответственно в 1,5 и 2,4 раза) и корней (в 1,6 и 1,8 раза) по сравнению с контролем (см. рис. 1, Б). Сроки начала цветения в опытных вариантах не отличались от таковых в контроле, но продуктивность цветения возросла на 19-23 \% по сравнению с контролем. В мае при пересадке в открытый грунт (при дневной температуре $10-12{ }^{\circ} \mathrm{C}$ и ночной 2-5 ${ }^{\circ} \mathrm{C}$ ) приживаемость растений в вариантах КС и СС была от $100 \%$ (тагетис, петуния) до $80 \%$ (львиный зев), тогда как у контрольных растений она составила 60-70\%.

Важным показателем стрессоустойчивости растений служит состояние мембранной системы клеток листьев. Сохранение избирательной проницаемости плазмалеммы для некоторых ионов и для молекул воды позволяет поддерживать гомеостаз клеток (25). Для его сохранения в клетке важно накопление ионов натрия в вакуоле, поддержание физиологической 


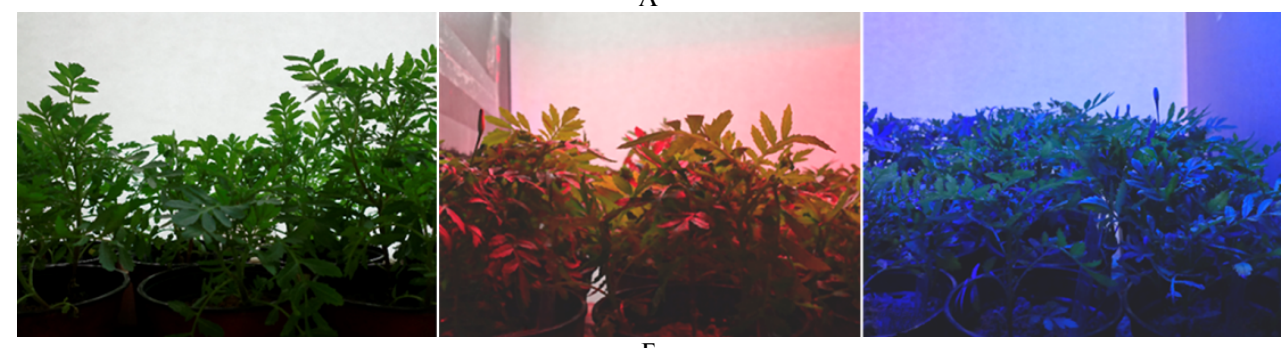

Б
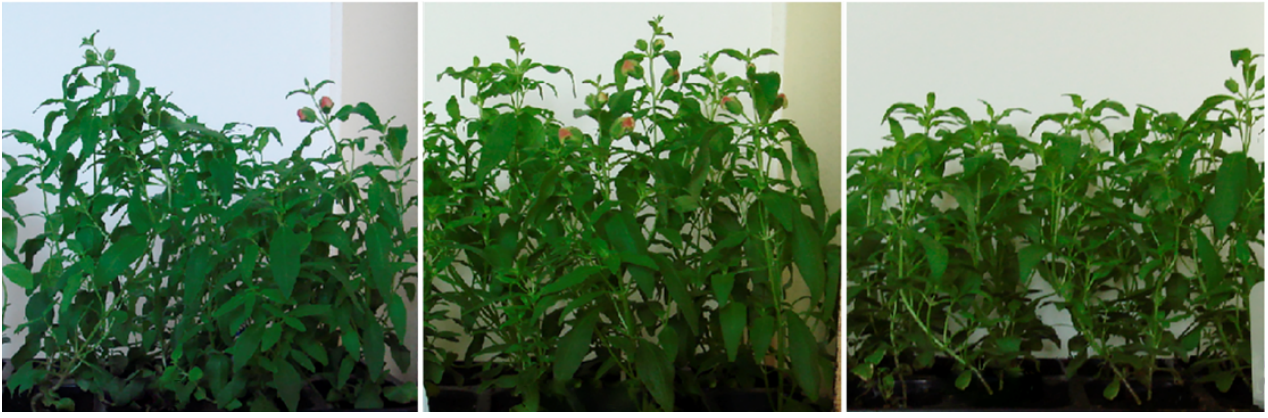

Рис. 1. Растения тагетиса (Tagetis panula L., низкорослый сорт Karmen) (А) и львиного зева (Antirrhinum majus nanum L., низкорослый сорт Flora shower white) (Б) после 12-часовой досветки в течение 35 сут: слева направо - контроль (только естественное освещение), освещение красным $(\max \lambda=600$ нм) и синим $(\max \lambda=400$ нм) светом; светодиодные лампы модели ПС-2 (УСС-12) («Фокус», Россия).

Физиологические показатели у декоративных растений при холодовом стрессе в зависимости от досветки узкоспектральным светом (вегетационный опыт, 5кратная повторность)

\begin{tabular}{|c|c|c|c|c|c|c|c|c|c|c|}
\hline \multirow{3}{*}{$\begin{array}{l}\text { Пока- } \\
\text { затель }\end{array}$} & \multicolumn{2}{|c|}{$\mathrm{K}$} & \multicolumn{4}{|c|}{$\mathrm{KC}$} & \multicolumn{4}{|c|}{$\mathrm{CC}$} \\
\hline & \multirow{2}{*}{$\frac{1}{\mathrm{eд.}}$} & \multirow{2}{*}{$\begin{array}{c}2 \\
\text { ед. }\end{array}$} & \multicolumn{2}{|l|}{1} & \multicolumn{2}{|l|}{2} & \multicolumn{2}{|l|}{1} & \multicolumn{2}{|l|}{2} \\
\hline & & & ед. & $\%$ & ед. & $\%$ & ед. & $\%$ & ед. & $\%$ \\
\hline \multicolumn{11}{|c|}{ Таге т и с (Tagetis panula L.), с о р т Karmen } \\
\hline A & $41,0 \pm 1,8$ & $45,3 \pm 2,1$ & $27,4 \pm 1,3$ & $67^{*}$ & $37,3 \pm 1,7$ & $82 *$ & $40,6 \pm 1,5$ & 99 & $39,6 \pm 1,7$ & $88^{*}$ \\
\hline 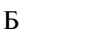 & 0,4 & $10,8 \pm 0,5$ & 2 & $38^{*}$ & & $63^{*}$ & & $16^{*}$ & & $11^{*}$ \\
\hline B & $0,48 \pm 0,02$ & $0,65 \pm 0,04$ & $1,07 \pm 0,10$ & $223^{*}$ & $0,46 \pm 0,09$ & $71^{*}$ & $0,50 \pm 0,03$ & 104 &, 02 & $39^{*}$ \\
\hline \multicolumn{11}{|c|}{ Л ь в и н ы й з е в (Antirrhinum majus nanum L.), с о р т Flora shower white } \\
\hline A & $7 \pm 2,4$ & $82,4 \pm 4,1$ & $63,1 \pm 3,5$ & 108 & $74,6 \pm 3,9$ & 91 & $85,2 \pm 4,1$ & $143^{*}$ & $51,9 \pm 2,1$ & $63^{*}$ \\
\hline b & $\pm 0,5$ & 0,6 & 3 & $71^{*}$ & 2 & $20^{*}$ & 4 & $85^{*}$ & 3 & $28^{*}$ \\
\hline B & 5 & 1 , & 6 & $110^{*}$ & 1 , & 98 & 1 & $142^{*}$ & 12 & $111^{*}$ \\
\hline 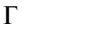 & $\pm 0,42$ & $10,20 \pm 0,20$ & & & & & & 101 & & $121^{*}$ \\
\hline \multicolumn{11}{|c|}{ П е т у н и я (Petunia hybrida L.), с о р т Mambo blue } \\
\hline A & $1 \pm 0,7$ & $55,3 \pm 2,3$ & $24,3 \pm 1,3$ & 110 & $26,3 \pm 1,2$ & $48^{*}$ & $32,4 \pm 1,5$ & $147^{*}$ & 1,3 & $49^{*}$ \\
\hline Б & $\pm 0,4$ & $14,0 \pm 0,5$ & 2 & $58^{*}$ & & $42^{*}$ & & $51^{*}$ & & $32 *$ \\
\hline B & $3 \pm 0,12$ & $1,39 \pm 0,13$ & $1,52 \pm 0,16$ & $124^{*}$ & $1,07 \pm 0,11$ & $77^{*}$ & $1,49 \pm 0,13$ & $121^{*}$ & $0,95 \pm 0,08$ & $68^{*}$ \\
\hline$\underline{\Gamma}$ & $3,05 \pm 0,19$ & $3,24 \pm 0,16$ & $2,88 \pm 0,14$ & 95 & $3,53 \pm 0,21$ & 109 & $2,93 \pm 0,16$ & 96 & $4,43 \pm 0,24$ & $137^{*}$ \\
\hline \multicolumn{11}{|c|}{ 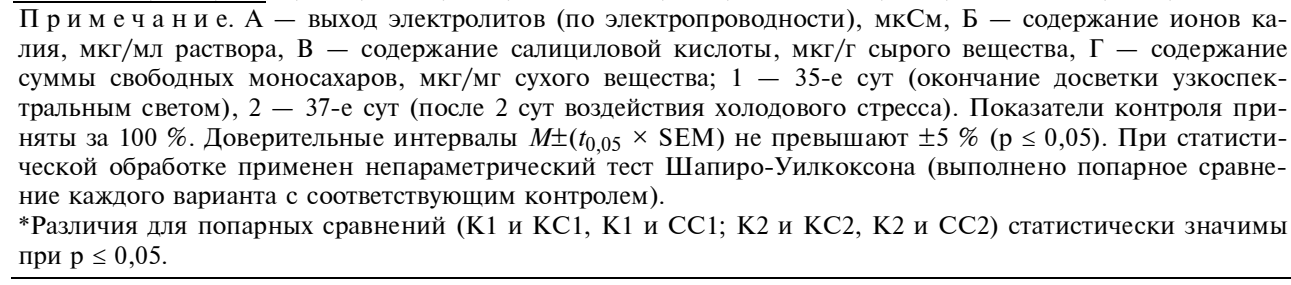 } \\
\hline
\end{tabular}

концентрации ионов калия и высокого соотношения $\mathrm{K}^{+} / \mathrm{Na}^{+}$в цитоплазме (26), то есть увеличение выхода ионов калия указывает на негативные изменения во внутренней среде клетки. В тканях листьев у тагетиса после окончания досветки избирательная проницаемость мембран снизилась в варианте КС и осталась в пределах контроля в случае СС, тогда как у растений львиного зева и петунии выход электролитов под воздействием КС 
возрос по сравнению с контролем незначительно, тогда как в случае СС значимо ( $\mathrm{p} \leq 0,05)$ (табл.). При этом выход ионов калия существенно снизился $(\mathrm{p} \leq 0,05)$ в обоих вариантах опыта относительно контроля, что позволило сохранить высокое соотношение $\mathrm{K}^{+} / \mathrm{Na}^{+}$в цитоплазме клеток растений, подвергавшихся досветке.

У всех растений воздействие низкими положительными температурами привело к нарушению полупроницаемости мембран, но в контроле оно было максимальным. Наиболее устойчивыми к кратковременному холодовому стрессу оказались растения петунии, досвеченные КС и СС: в тканях их листьев выход электролитов снизился на 51-52 \% по сравнению с контролем ( $\leq \leq 0,05)$, тогда как у тагетиса снижение составило $12-18 \%$, а у львиного зева $-9-37 \%$ ( $\leq 0,05)$. При воздействии КС и особенно СС у всех растений достоверно (p $\leq 0,05)$ снизился выход ионов калия. Следует отметить, что при досветке узкоспектральным светом восстановление растений после окончания холодового стресса шло быстрее, особенно в варианте КС, тогда как контрольные растения не только медленнее восстанавливались, но и снижалась их декоративная оценка (рис. 2).

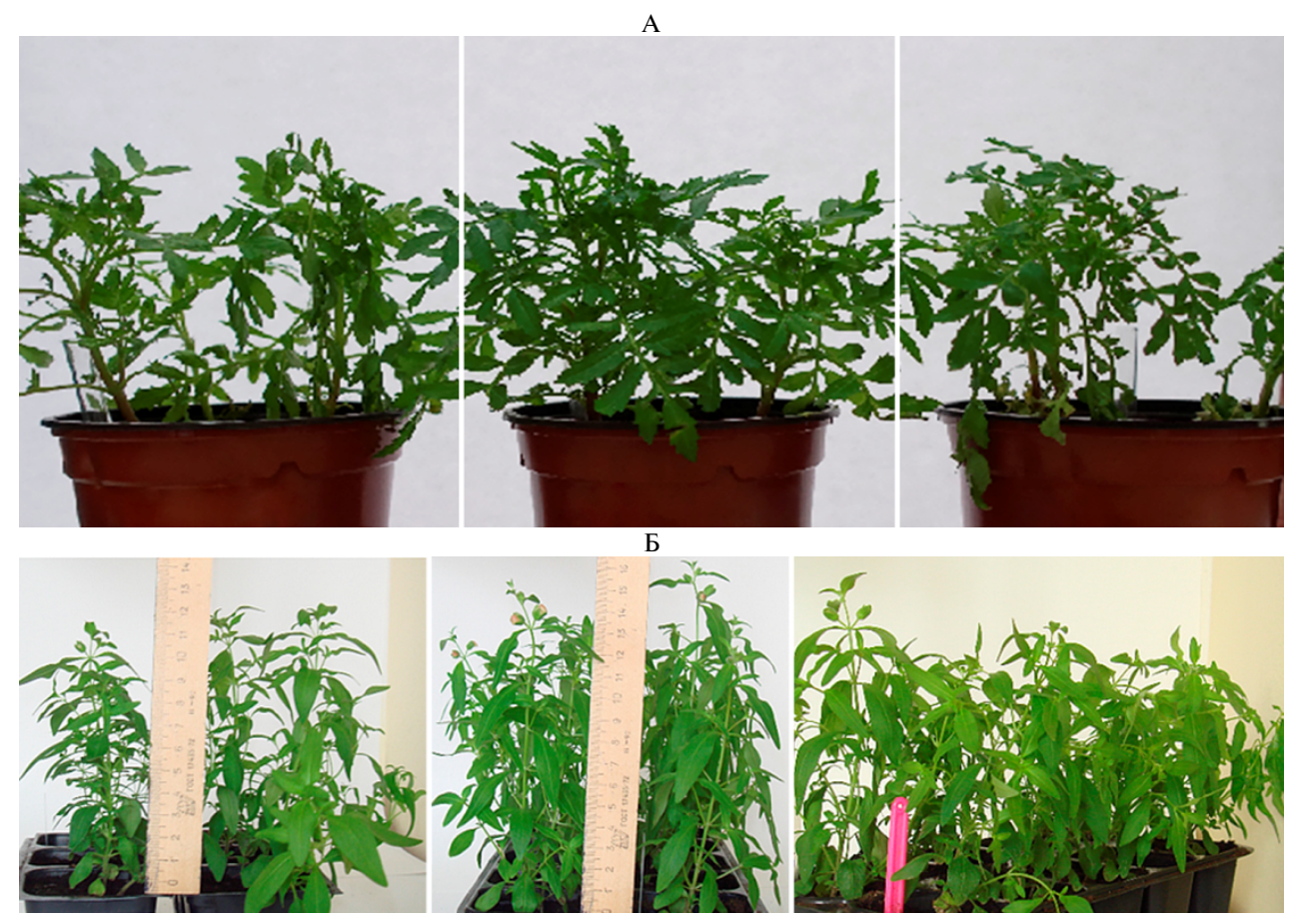

Рис. 2. Досвеченные растения тагетиса (Tagetis panula L., низкорослый сорт Karmen) (A) и львиного зева (Antirrhinum majus nanum L., низкорослый сорт Flora shower white) (Б) после холодового стресса (на 37-е сут опыта): слева направо - контроль (только естественное освещение), освещение красным ( $\max \lambda=600$ нм) и синим ( $\max \lambda=400$ нм) светом; светодиодные лампы модели ПС-2 (УСС-12) («Фокус», Россия).

Досветка рассады декоративных растений узкоспектральным светом не повлияла на содержание водорастворимых углеводов в тканях листьев (см. табл.). Воздействие холодового стресса привело к увеличению содержания моносахаров у львиного зева и петунии в обоих вариантах (КС и СС) по сравнению с контролем, при этом наиболее существенно возросло (на $21 \%$ у львиного зева и на 37 \% петунии) содержание водорастворимых углеводов под влиянием СС. Известно, что моносахара, не только служат энергетическим ресурсом, но и играют существенную протекторную роль при сохранении гомеостаза клеток при стрессе (27). Веро- 
ятно, в нашем опыте они способствовали формированию реакции растений, обеспечивающей их выживание в стрессовых условиях гипотермии.

Одним из триггеров протекторного сигнального пути служит салициловая кислота. Ее роль в запуске и регуляции адаптационного механизма неоднозначна (16). Недостаток или избыток СК может вызвать усиление стрессового воздействия, так как количества СК и АФК коррелируют, а с содержанием СК связана инициация каскада защитных реакций (28), который светозависим и действует в комплексе с другими протекторными механизмами (29). У всех растений после окончания досветки количество СК возросло по сравнению с контролем, наиболее существенно - под влиянием КС у тагетиса (на $223 \%$ по сравнению с контролем) (см. табл.). По-видимому, в этом случае начал меняться гормональный баланс в тканях листьев и, как следствие, перестраивался весь метаболизм растений. На 2-е сут после холодового стресса содержание СК у растений тагетиса в обоих вариантах снизилось как по сравнению с контролем (на 29-61 \%), так и относительно показателей до воздействия холодового стресса: в варианте $\mathrm{KC} \mathrm{-} \mathrm{в} \mathrm{2,3} \mathrm{раза,} \mathrm{СС} \mathrm{-} \mathrm{в} \mathrm{2,0} \mathrm{раза.} \mathrm{У} \mathrm{растений} \mathrm{львиного} \mathrm{зева} \mathrm{и} \mathrm{пе-}$ тунии после окончания досветки КС и СС содержание СК значимо не изменилось по сравнению с контролем. Воздействие холодового стресса на досвеченные КС и особенно СС растения обоих видов привело к увеличению содержания СК - на 9 и $14 \%$ (p $\leq 0,05)$ (вариант КС) и на 21 и $37 \%$ $(\mathrm{p} \leq 0,05)$ (вариант $\mathrm{CC})$ соответственно у львиного зева и петунии.

Следует отметить, что растения тагетиса при досветке синим светом после воздействия холодового стресса быстро потеряли тургор, началось повреждение краев листьев. Растения в этом варианте опыта долго восстанавливались от повреждений, поздно зацвели, почти треть из них погибла (см. рис. 2, А). Менее выраженные признаки повреждений были у контрольных растений, они перенесли охлаждение лучше, но были менее декоративны (слабое ветвление, мелкие бутоны). Растения, досвеченные красным светом, имели хороший тургор листьев, у них отмечали раскрытие цветочных бутонов. Возможно, изменение гормонального статуса тканей тагетиса при досветке красным светом способствовало включению протекторного каскада реакций, которые нивелировали негативные последствия от охлаждения. Изменение соотношения гормонов под воздействием синего света не дало положительного эффекта. Растения львиного зева (см. рис. 2, Б) и петунии быстро восстановились после холодового стресса в обоих вариантах опыта (КС и СС): их тургор, надземная масса и габитус почти не изменились. При этом в контроле восстановление после холодового стресса у львиного зева и петунии шло медленно, снизилась масса надземных (на $15 \%$ ) и подземных (на $10 \%$ ) органов, декоративная оценка неконтрольных растений была ниже, чем при досветке.

В инициацию каскадных реакций, формирующих ответ на абиотический стресс, также вовлечена абсцизовая кислота (19). Этот гормон определяли только в тканях растений тагетиса. После окончания досветки содержание АБК в тканях растений возросло под влиянием КС (до $0,191 \pm 0,02$ мКг/г) и несколько снизилось (до $0,037 \pm 0,005$ мкг/г) в случае СС по сравнению с контролем $(0,043 \pm 0,003$ мкг/г). После воздействия холодового стресса количество АБК в тканях листьев в варианте СС существенно увеличилось по сравнению с исходным $(0,066 \pm 0,008$ мкг/г), в контроле - почти не изменилось $(0,048 \pm 0,004$ мкг/г), а при досветке красным светом - снизилось в 5 раз (до $0,038 \pm 0,004$ мкг/г). То есть эти результаты также свидетельствуют в пользу нашего предположения об изменении гормонального баланса в тканях листьев тагетиса при досветке и, как 
следствие, о перестройке всего метаболизма растений.

Возможно, свет различного спектрального состава включал разные пути активации протекторных механизмов. Триггерную функцию в такой активации могут выполнять и СК, и АБК, их сигнальные пути частично перекрываются. Формируется информационная сеть с антагонистическими и синергическими звеньями (27). Возможно, в случае СС салициловая кислота способствовала быстрому переключению метаболических процессов на адаптационный режим, а при досветке красным светом этот механизм мог включаться после выброса АФК, и салициловая кислота не вовлекалось в экспрессию защитных генов.

Таким образом, совокупность физиологических и биохимических изменений в тканях листьев декоративных растений (габитус, морфология, накопление биомассы, выход электролитов, содержание ионов калия, салициловой и абсцизовой кислот, суммы свободных моносахаров (глюкозы и фруктозы) дает возможность предположить, что досветка спектральным светом способствует началу перестройки метаболических процессов и активации неспецифических протекторных механизмов, сохраняющих ионный и окислительно-восстановительный гомеостаз клеток. Впервые показано, что досветка рассады узкоспектральным светом позволила этим растениям успешно адаптироваться к холодовому стрессу. При пересадке в открытый грунт (в условиях ночной температуры $2-5{ }^{\circ} \mathrm{C}$ ) их приживаемость после досветки составила 80-100 \% против 60-70 \% в контроле. Следовательно, добавление узкоспектрального света от светодиодных панелей к естественному освещению при выращивании рассады декоративных растений позволит снизить их гибель от резкой смены условий обитания при использовании для озеленения территорий.

\section{ЛИТЕ РАТУ Р А}

1. Olle M., Viršile A. The effect of light emmiting diode lighting on greenhouse plant grows and quality. Agricultural and Food Science, 2013, 22(2): 223-234 (doi: 10.23986/afsci.7897).

2. Аверчева О.В., Беркович Ю.А., Ерохин А.Н., Жигалова Т.В., Погосян С.И., Смоляна С.О. Особенности роста и фотосинтеза растений китайской капусты при выращивании под светодиодными светильниками. Физиология растений, 2009, 56(1): 17-16.

3. Vanninen I., Pinto D.M., Nissinen A.I., Johansen N.S., Shipp L. In the light of new greenhouse technologies: 1. Plant-mediated effects of artificial lighting on arthropods and tritrophic interactions. Annals of Applied Biology, 2010, 157(3): 393-414 (doi: 10.1111/j.17447348.2010.00438).

4. Colquhoun T.A., Schwieterman M.L., Gilbert J.L., Joworski E.A., Langer K.M., Jones C.R., Rushing G.V., Hunter T.M., Olmsted J., Clark D.G., Folta K.M. Light modulation of volatile organic compounds from petunia flowers and select fruits. Postharvest Biology and Technology, 2013, 86: 37-44 (doi: 10.1016/j.postharvbio.2013.06.013).

5. Causin H.F., Jauregui R.N., Barneix A.J. The effect of light spectral quality on leaf senescence and oxidative stress in wheat. Plant Sci., 2006, 171(1): 24-33 (doi: 10.1016/j.plantsci.2006.02.009).

6. Chinnusamy V., Zhu J., Zhu J.-K. Gene regulation during cold acclimation in plants. Physiologia Plantarum, 2006, 126(1): 52-61 (doi: 10.1111/j.1399-3054.2006.00596.x).

7. Crosatti C., Rizza F., Badeck F.W., Mazzucotelli E., Cattivelli L. Harden the chloroplast to protect the plant. Physiologia Plantarum, 2013, 147(1): 55-63 (doi: 10.1111/j.13993054.2012.01689.x).

8. van Gelderen K., Kang C., Pierik R. Light signaling, root development, and plasticity. Plant Physiol., 2018, 176(2): 1049-1060 (doi: 10.1104/pp.17.01079).

9. Креславский В.Д., Карпентиер Р., Климов В.В., Мурата Н., Аллахвердиев С.И. Молекулярные механизмы устойчивости фотосинтетического аппарата к стрессу. Биологические мембраны, 2007, 24(3): 195-217.

10. Trotta A., Rahikainen M., Konert G., Finazzi G., Kangasjärvi S. Signalling crosstalk in light stress and immune reactions in plants. Philosophical Transactions of the Royal Society B: Biological Sciences, 2014, 369(1640): 20130235 (doi: 10.1098/rstb.2013.0235).

11. Pennycooke J.C., Cox S., Stushnoff C. Relationship of cold acclimation, total phenolic content and antioxidant capacity with chilling tolerance in petunia (Petunia $\times$ hybrida). Environ. Exp. 
Bot., 2005, 53(2): 225-232 (doi: 10.1016/j.envexpbot.2004.04.002).

12. Patton A.J., Cunningham S.M., Jolenec J.J., Reicher Z.J. Difference in freeze tolerance of zoysiagrasses. II. Carbohydrate and proline accumulation. Crop Sci., 2007, 47(5): 2170-2181 (doi: 10.2135/cropsci2006.12.0784).

13. Crossatti C., Polverino de Laureto P., Bassi R., Cattivelli L. The interaction between cold and light control the expression of the cold regulated barley gene cor $14 b$ and the accumulation of the corresponding protein. Plant Physiol., 1999, 199: 571-599 (doi: 10.1104/pp.119.2.671).

14. Zhao Y., Zhou J., Xing D. Phytochrome B-mediated activation of lipoxygenase modulates an excess red light-induced defense response in Arabidopsis. J. Exp. Bot., 2014, 65(17): 4907-4918 (doi: 10.1093/jxb/eru247).

15. Rejeb I.B., Pastor V., Mauch-Mani B. Plant responses to simultaneous biotic and abiotic stress: molecular mechanisms. Plants, 2014, 3(4): 458-475 (doi: 10.3390/plants3040458).

16. Yuan S., Lin H.-H. Role of salicylic acid in plant abiotic stress. Zeitschrift fur Naturforschung $C$, 63(5-6): 313-320 (doi: 10.1515/znc-2008-5-601).

17. Janda T., Horváth E., Szalai G., Páldi E. Role of salicylic acid in the induction of abiotic stress tolerance. In: Salicylic acid: a plant hormone /S. Hayat, A. Ahmad (eds.). Springer, 2007: 91-150 (doi: 10.1007/1-4020-5184-0_5).

18. Махдавиан К., Калантари Х.М., Горбанли М. Влияние салициловой кислоты на формирование окислительного стресса, индуцированного УФ-светом в листьях перца. Физиология растений, 2008, 55(4): 620-623.

19. Shi Y., Yang S. ABA regulation of cold stress response in plants. In: Abscisic acid: metabolism, transport and signaling /D.P. Zhang (ed.). Springer, 2014: 337-363 (doi: 10.1007/978-94-0179424-4_17).

20. Воронкова Т.В., Шелепова О.В. Способ определения содержания водорастворимых углеводов и крахмала из одной навески. Патент 2406293 RU МПК A01G 7/00 2006/01.

21. Кондратьева В.В., Семенова М.В., Воронкова Т.В., Шелепова О.В. Изменение некоторых физиолого-биохимических характеристик тканей почки возобновления тюльпана Эйхлера (Tulipa Eichleri Regel) в процессе зимовки. Научные ведомости Белгородского государственного университета (Естественные науки), 2011, 3(98), вып. 14/1: 339-345.

22. Шелепова О.В., Кондратьева В.В., Воронкова Т.В, Олехнович Л.С., Енина О.Л. Физиолого-биохимические аспекты длительного воздействия на растения мяты света неизменного спектрального состава. Бюллетень Главного ботанического сада, 2012, 2: 68-73.

23. Hammer O., Harper D.A.T., Ryan P.D. PAST: Palaeontological Statistics software package for education and data analysis. Palaeontologia Electronica, 2001, 4(1): art. 4, 9 pp.

24. Петровская-Баранова Т.П. Физиология адаптации и интродукция растений. М., 1983.

25. Тарчевский И.А. Метаболизм растений при стрессе. Казань, 2001.

26. Munns R., Tester M. Mechanisms of salinity tolerance. Annu. Rev. Plant Boil., 2008, 59: 651681 (doi: 10.1146/annurev.arplant.59.032607.092911).

27. Трунова Т.И. Растение и низкотемпературный стресс. 64-е ежегодные Тимирязевские чтения. М., 2005.

28. Mateo A., Frunk D., Mühlenbock P., Kular B., Mullineaux P.M., Karpisnki S. Controlled levels of salicylic acid and required for optimal photosynthesis and redox homeostasis. J. Exp. Bot., 2006, 57(8): 1795-1807 (doi: 10.1093/jxb/erj196).

29. Bechtold U., Karpinski S., Mullineaux P. The influence of the light environment and photosynthesis on oxidative signaling responses in plant-biotrophic pathogen interaction. Plant Cell \& Environment, 2005, 28: 1046-1055 (doi: 10.1111/j.1365-3040.2005.01340.x).

\title{
ФГБНУ Главный ботанический сад
}

\section{им. Н.В. Цииина РАН,}

Поступила в редакцию

127276 Россия, г. Москва, Ботаническая ул., 4, 10 июля 2018 года

e-mail: lab-physiol@mail.ru $₫$, winterness@yandex.ru, shelepova-olga@mail.ru

Sel'skokhozyaistvennaya biologiya [Agricultural Biology], 2019, V. 54, № 1, pp. 121-129

\section{THE SPECTRAL LIGHT INFLUENCE ON YOUNG ORNAMENTAL PLANTS' RESISTANCE TO SHORT-TERM COLD STRESS}

\author{
V.V. Kondratieva, T.V. Voronkova, L.S. Olekhnovich, G.F. Bidyukova, O.L. Enina, \\ O.V. Shelepova
}

Tsitsin Main Botanical Garden RAS, 4, Botanicheskaya ul., Moscow, 127276 Russia, e-mail lab-physiol@mail.ru ( $\triangle$ corresponding author),winterness@yandex.ru, shelepova-olga@mail.ru ORCID:

Kondratieva V.V. orcid.org/0000-0003-3934-9288

Bidyukova G.F. orcid.org/0000-0002-0740-947X

Voronkova T.V. orcid.org/0000-0002-6112-271X

Enina O.L. orcid.org/0000-0002-8971-6384 


\section{Abstract}

LED light sources allow for variations in the spectral composition which makes it possible to evaluate the effect of light with narrow spectral width on plants performance. The combination of such lighting with natural lighting can significantly change the direction and intensity of metabolic processes in plants to adapt to changing environmental conditions. In the present paper, we showed for the first time that additional illumination with narrow-spectrum light allows the seedlings of ornamental plants to successfully adapt to cold stress. The aim of our work was to estimate the effect of red light $(600 \mathrm{~nm})$ and blue light $(400 \mathrm{~nm})$ from LED panels on adaptation of tagetes (Tagetis panula L.) cultivar Karmen, snapdragon (Antirrhinum majus nanum L.) cultivar Flora shower white and petunias (Petunia hybrida L.) cultivar Mambo blue seedlings to spring frosts when transplanting to open ground. These plants are often used in landscaping settlements and are exposed to low positive and zero temperatures, especially in the first days after transplanting to open ground. The experiment was carried out in a greenhouse $\left(18{ }^{\circ} \mathrm{C}\right.$, humidity $\left.85 \%\right)$. During thirty days, one third of the plants were additionally red lightened (RL), and one third ones were blue lightened (BL) using Focus MC2 (JCC-12) LED panels (Russia) for 12 hours after the end of daylight hours. A third of the plants were grown under natural light only $(\mathrm{C})$. After the end of the LED illumination period, a half of the plants in each variant were placed in the chamber with $2{ }^{\circ} \mathrm{C}$ for 24 hours. The second half plants were control without cooling. The effectiveness of lighting was assessed by the decorative state of plants, the change in the selective permeability of membranes, the content of salicylic and abscisic acids, the triggers of the cascade of protector reactions in the leaf tissues, and the survival of plants transplanted to the open ground. Our experiments showed that additional lightening with blue and red light contributes to seedling resistance to low positive temperatures. In RL- and BL-exposed plants, the leaf turgor was quickly restored, the habitus of plants was preserved, and budding began. In these variants, the cell membrane stabilization was noted, i.e. i.e. an increase in the outlet of potassium ions was two times lower than in the control. The changes of cell membranes was estimated by output of electrolytes from the $0.25 \mathrm{~g}$ leaves measured potentiometrically (ITAN, OOO SPE Tom'analit, Russia) with an ion-selective electrode (Elit-031, OOO NIKO ANALIT, Russia). Abscisic acid (ABA) and salicylic acid (SA), the important triggers and tuners of cascade responses to abiotic stress, were determined in a single sample, at the final stage, by isocratic HPLC method (Stayer system, ZAO Aquilon, Russia), with column PR-18 (250/4.6 mm) (Phenomenex, Inc., USA). ABA concentration in leaves of RL-exposed tagetes plants increased 4.4-fold and the SA 3.3-fold compared to the control, and in BL-exposed tagetes only SA content increased 1.4-fold $(\mathrm{p} \leq 0.05)$. After cold exposure, the RL plants restored turgor, while in BL the restoration was slower and the leaf infiltration began. Similar changes were in control. In snapdragons and petunias, blue light also caused a 1.5-fild increase in the SA level in leaves, while red light led to insignificant changes. After cold stress, the RL- and SS-exposed plants of these species quickly recovered, their habitus was almost as in unaffected plants. The control plants recovered more slowly, and their decorativeness was worse. The survival rate of RL plants replanted to open ground was $100 \%$ for tagetes and petunias, and $85-90 \%(\mathrm{p} \leq 0.05)$ for snapdragons. In BL-exposed plants, these indicators were $70 \%(\mathrm{p} \leq 0.05)$ for tagetes and 85-90\% $(\mathrm{p} \leq 0.05)$ for petunias. The rooting of the control plants not exposed to RL or BL and subjected to the cold stress reached $60-70 \%(\mathrm{p} \leq 0.05)$. The physiological and biochemical changes that we identified in the leaves of the seedlings of ornamental plants suggest that spectral light facilitates the modulation of plant metabolism and activates non-specific protective mechanisms aimed at preserving the ionic and redox cell homeostasis. An exposure of growing seedlings of ornamental plants to light with narrow spectral width, in addition to natural light, can be very effective to reduce the loss of re-planted plants from spring frosts.

Keywords: Tagetis panula L., tagetes cv. Karmen, Antirrhinum majus nanum L., snapdragon cv. Flora shower white, Petunia hybrida L., petunias cv. Mambo blue, narrow spectral light, cold stress, cell membranes, water soluble carbohydrates, salicylic acid, abscisic acid, ABA.

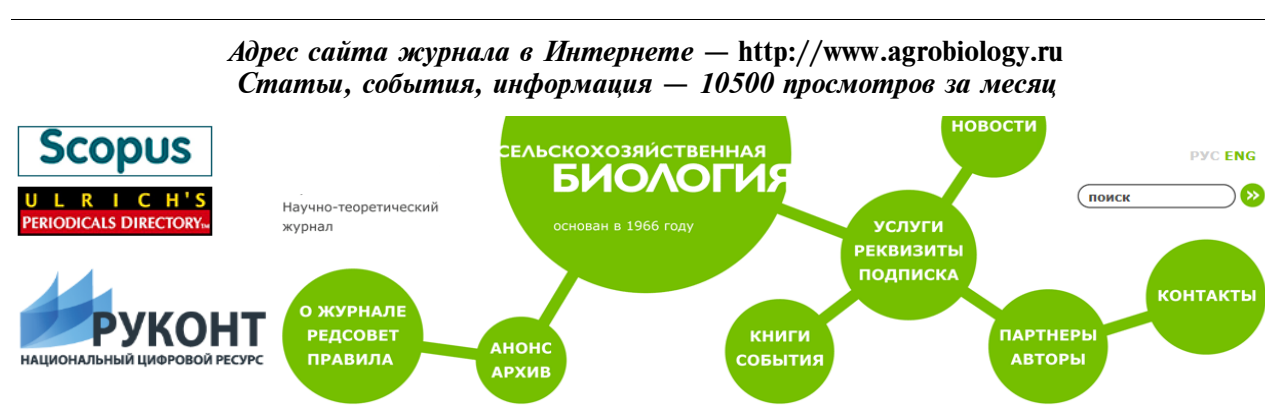

